\title{
Impact of Frontline Demonstration of KVK on the Yield of Paddy (Sahbhagi dhan) in Nalanda District of Bihar, India
}

\author{
N.K. Singh ${ }^{1 *}$, Sanjeev Kumar ${ }^{1}$, Wazid Hasan ${ }^{2}$ and Anand Kumar ${ }^{1}$ \\ ${ }^{1}$ KVK, Harnaut, Nalanda, India \\ ${ }^{2}$ KVK, Jahanabad, India \\ *Corresponding author
}

\section{A B S T R A C T}

Ke y w or d s
Paddy, Sahbhagi,
$\begin{aligned} & \text { FLD, Impact, } \\ & \text { Adoption Gap, B: C } \\ & \text { ratio }\end{aligned}$
Article Info
$\begin{aligned} & \text { Accepted: } \\ & \text { 28 February } 2018 \\ & \text { Available Online: } \\ & \text { 10 March } 2018\end{aligned}$

\section{Introduction}

Paddy (Oryza sativa) is the most widely grown tropical cereal and over 400 million tonnes of milled rice is produced each year. The importance of rice has been recognized for many countries. In India it was once known as "Dhanya" meaning the sustainer of the human race. Rice is a stable food of south Asia and a vast number of people are employed in its cultivation. India is one of the world's largest producers of white rice and brown rice. India could achieve a record rice production of 100 million tonnes in 2010-11 crop year on the back of better monsoon this year. India's rice production reached to a record high of 104.32 million tonnes in 20112012 crop year (July-June). Rice is one of the chief grains of India moreover, this country has largest area under rice cultivation, as it is one of the principal food crops. It is in fact the dominant crop of the country. India is one of the leading producers of this crop. Rice is the basic food crop and being a tropical plant.

\section{Materials and Methods}

Frontline demonstration (FLD's) on paddy was conducted by Krishi Vigyan Kendra, Harnaut Nalanda (Bihar) during the year 2014 to 2016 in different villages like junedi, sarilchak, Aoknanma, Sermera, Gorma, 
Malama and charuipar of district Nalanda. 143 number of demonstration was conducted in seven villages. In general soil of the area under study was loam or sandy loam with low to medium fertility status.

The component demonstration of frontline technology in paddy was comprised of improved variety "Sahbhagi Dhan", Proper tillage, proper seed rate, sowing method, balance dose of fertilizer $(100 \mathrm{~kg} \mathrm{~N}+40 \mathrm{~kg}$ $\mathrm{p}_{2} \mathrm{O}_{5}+20 \mathrm{~kg} \mathrm{k}_{2} \mathrm{O} / \mathrm{ha}$ ), proper irrigation, weed management and protection measures (Table 1). Total 60 ha area was covered in three consecutive years. In the demonstration, one control plot was also kept where farmers practices was carried out.

The FLD was conducted to study the technology gap between the potential yield and demonstrated yield, extension gap between demonstrated yield and yield under existing practices and technology index. The yield data were collected from both the demonstration and farmers practice by random crop cutting method and analyzed by using simple statistical tools.

The technology gap, extension gap and technology index (samui et al., 2000) were calculated by using formula (Eq. 1 to 4 ) as given below.

Demonstration yield- Farmers yield Percent increase yield $=$

Farmers yield (Eq.1)

Technology gap = Potential yieldDemonstrated yield. (Eq.2)

Extension gap $=$ Demonstrated yield-Yield under existing practices. (Eq.- 3)

Potential yield - Demonstrated yield Technology index= -------------------- x 100 Potential yield (Eq. - 4)

\section{Results and Discussion}

The gap between the existing and recommended technologies of paddy in district Nalanda is presented in table 1. Full gap was observed in case of use of HYVs, sowing methods, seed treatment, fertilizer does and weed management and partial gap was observed in plant protection measures which definitely was the reason of not achieving potential yield. Farmer was not aware about recommended technology. Farmers in general used local or old age varieties-instead of the recommended high yielding resistant varieties. Unavailability of seed in time and lack of awareness were the main reasons. Farmers followed broadcast method of sowing against the recommended line sowing and because of this, they applied higher seed rate than the recommended.

\section{Yield}

During three years of frontier technologies results obtained are presented in table 2 . The results revealed that due to front line demonstration on paddy on average yield was recorded $42.17 \mathrm{q} / \mathrm{ha}$ under demonstrated plots as compared farmers practice $26.46 \mathrm{q} / \mathrm{ha}$.

The highest yield in the FLD plot was 46.92 q/ha in 2014 and in farmers practice 33.26 q/ha during 2016 and lowest yield was recorded in 2015-16. This results clearly indicated that the higher average grain yield in demonstration plots over the years compare to local check due to knowledge and adoption of full package of practices that is appropriate varieties such as sahbhagi Dhan, timely sowing, seed treatment with trichoderma@5 $\mathrm{g} / \mathrm{kg}$ of seeds, use of balanced dose of fertilizer $\left(100 \mathrm{~kg} \mathrm{~N}+40 \mathrm{~kg} \mathrm{P}_{2} \mathrm{O} 5+20 \mathrm{~kg} \mathrm{~K}_{2} \mathrm{O}\right.$ /ha), method and time of sowing, timely weed management and need based plant protection. The average yield of paddy (Sahbhagi Dhan) increased 54.28 percent. 
Table.1 Differences b/w technological intervention and farmers practices under FLD on p2addy (drought resistant)

\begin{tabular}{|c|c|c|c|}
\hline Particulars & Technological intervention & Existing practices & Gap \\
\hline Variety & Sahbhagi dhan & Old and degenerated & Full gap \\
\hline Land preparation & Three ploughing and pudling & $\begin{array}{l}\text { Three ploughing and } \\
\text { pudling }\end{array}$ & Nil \\
\hline Seed rate & $15-20 \mathrm{~kg} / \mathrm{ha}$ & $40 \mathrm{~kg} / \mathrm{ha}$ & $\begin{array}{l}\text { Higher } \\
\text { seed rate }\end{array}$ \\
\hline Seed treatment & Trichoderma@5gm/kg seed & No S.T & Full gap \\
\hline $\begin{array}{l}\text { Transplanting/Dir } \\
\text { ect seeding }\end{array}$ & Transplanting & Transplanting & Nil \\
\hline Fertilizer dose & $100 \mathrm{~kg} \mathrm{~N}+40 \mathrm{~kg} \mathrm{P} 205+20 \mathrm{~kg} \mathrm{~K}_{2} \mathrm{O} / \mathrm{ha}$ & $150 \mathrm{~kg} \mathrm{~N}+0+0$ & $\begin{array}{l}\mathrm{P} \& \mathrm{~K} \text { Nil } \\
\& \text { higher } \\
\text { dose of } \mathrm{N}\end{array}$ \\
\hline $\begin{array}{l}\text { Weed } \\
\text { management }\end{array}$ & $\begin{array}{l}\text { Two mechanical weeding at per } \\
\text { need }\end{array}$ & No weeding & Full gap \\
\hline Plant protection & Need base & No plant protection & Full gap \\
\hline
\end{tabular}

Table.2 Gap in grain yield production and economic impact of paddy variety under FLDs

\begin{tabular}{|c|c|c|c|c|c|c|c|c|c|c|c|c|c|}
\hline \multirow[t]{3}{*}{ Year } & \multirow[t]{3}{*}{ Variety } & \multirow{3}{*}{$\begin{array}{l}\text { No. } \\
\text { of } \\
\text { FL } \\
\text { D }\end{array}$} & \multirow[t]{3}{*}{$\begin{array}{l}\text { Area } \\
\text { (ha) }\end{array}$} & \multicolumn{2}{|c|}{$\begin{array}{l}\text { Average yield } \\
\text { (q/ha) }\end{array}$} & \multirow[t]{3}{*}{$\begin{array}{l}\text { Percent } \\
\text { increase }\end{array}$} & \multirow{3}{*}{$\begin{array}{l}\text { Tech. } \\
\text { gap } \\
\text { (q/ha) }\end{array}$} & \multirow{3}{*}{$\begin{array}{l}\text { Exten } \\
\text { gap } \\
\text { (q/ha) }\end{array}$} & \multirow{3}{*}{$\begin{array}{l}\text { Tech. } \\
\text { index } \\
(\%)\end{array}$} & \multirow{2}{*}{\multicolumn{2}{|c|}{$\begin{array}{l}\text { Net return } \\
\text { (Rs /ha) }\end{array}$}} & \multirow{2}{*}{\multicolumn{2}{|c|}{ B.C ratio }} \\
\hline & & & & \multirow{2}{*}{ Demo } & \multirow{2}{*}{ FP } & & & & & & & & \\
\hline & & & & & & & & & & Demo & FP & Demo & FP \\
\hline $\begin{array}{l}2013- \\
14\end{array}$ & $\begin{array}{l}\text { Sahbhagi } \\
\text { dhan }\end{array}$ & 59 & 20 & 46.92 & 22.61 & 52 & 0.88 & 24.31 & 1.84 & 36304 & 8132 & 2.5 & 1.5 \\
\hline $\begin{array}{l}2014- \\
15\end{array}$ & $\begin{array}{l}\text { Sabhagi } \\
\text { dhan }\end{array}$ & 64 & 25.2 & 40.75 & 23.50 & 73 & 7.05 & 17.25 & 14.74 & 18340 & 4850 & 2.29 & 1.3 \\
\hline $\begin{array}{l}2015- \\
16\end{array}$ & $\begin{array}{l}\text { Sahbhagi } \\
\text { Dhan }\end{array}$ & 97 & 59.2 & 38.84 & 33.26 & 37.84 & 9.96 & 5.58 & 18.74 & 26400 & 20700 & 1.72 & 1.62 \\
\hline \multicolumn{2}{|c|}{ Total Average } & 220 & 104.4 & 42.17 & 26.46 & 54.28 & 5.96 & 15.71 & 11.77 & & & & \\
\hline
\end{tabular}

The yield of (Sahbhagi Dhan) paddy could be increased over the yield obtained under FLD on Paddy (Sahbhagi Dhan) farmers practices (Use of non-descriptive local variety, no. use of the balanced dose of fertilizers, untimely sowing/ transplanting and no control measures adopted for pest management) of paddy cultivation. The above findings are in similarity with the findings of Singh (2002).

\section{Technology gap}

The technology gap, the differences between potential yield and yield of demonstration plots were $0.88,7.05$ and $9.96 \mathrm{q} / \mathrm{ha}$ during 2013-14, 2014-15 and 2015-16 respectively on an average technology gap under three year FLD programmer was 5.96q/ha. The technology gap observed may be attributed to dissimilarity in the soil fertility status, agricultural practices and local climatic situation.

\section{Extension gap}

Extension gap of $24.31,17.25$ and $5.58 \mathrm{q} / \mathrm{ha}$ was observed during 2013-14, 2014-15 and 2015-16 respectively. On an average 
extension gap was observed 15.71q/ha which emphasized the need to educate the farmers through various extension means i.e. front line demonstration for adoption of improved production and protection technologies to revert the trend of wide extension gap. More and more use of latest production technologies with high yielding varieties will subsequently change this alarming trend of galloping extension gap.

\section{Technology index}

The technology index shows the feasibility of the demonstrated technology at the farmers field. The technology index varied from 1.84 to 18.74 percent (Table 2). On an average technology index was observed 11.77 percent during the three years of FLD programmes, shows the efficacy of good performance of technical interventions. This will accelerate the adoption of demonstrated technical intervention to increase the yield performance of paddy.

\section{Economic return}

The inputs and outputs prices of commodities prevailed during the study of demonstration were taken for calculating net return and benefit cast ratio (Table 2). The cultivation of paddy under improved technologies gave higher net return of Rs 36304, 18340 and Rs 26400 per ha respectively as compared to farmers practices. Similar findings were reporting by kirar et al., (2006). The benefit cast ratio of paddy cultivation under improved cultivation practices were 2.5,2.29 and 1.72 as compared to $1.5,1.3$ and 1.62 under farmers practices. This may be due to higher yield obtained under improved technology compared to local check (farmers practices) this finding is in corroboration with the findings of Mokidue et al., (2011), The producers of FLD was a significant positive result and provided the researcher an opportunity to demonstrate the productivity potential and profitability of the latest technology (interventions) under real farming situation, which they have been help in transfer of technology for long time. This could be circumvent some of the constraints in existing transfer of technology for long time. This could be circumvent some of the constraints in existing transfer of technology system in the district, Nalanda of Bihar. The productivity gain under FLD over existing practices of paddy cultivation created greater awareness and motivated the other farmers to adopt suitable production technology of paddy in the district The constraints faced by the farmers were different for different technologies. Efforts should therefore, be made by the extension agencies in their transfer of technology programmes to consider the constraints as perceived by the farmers in this investigations as well as personal. Therefore, for enhancing the production and productivity of paddy crop, strategy should be made for getting the more and more recommended technologies adopted by the farmers (Raj et al., 2013 and Sharma et al., 2011).

The variation in percent increase in the yield was found due to the lack of knowledge, and poor socio economic condition. Under sustainable agricultural practices, with this study it is concluded that the FLD programmes were effective in changing attitude skill and knowledge of improved package and practices of HYV of paddy adoption under drought condition.

\section{References}

Kiran BS, Narshine R, Gupta AK and Mukherji SC, 2016. Demonstration: An effective tools for increasing the productivity of Urd. Ind. Res. J. ext.edu. 6(3): 47-48

Mokidue I, Mohanty AK and Sanjay K. 2011. 
Corelating growth, yield and adoption of urd-bean technologies. Indian J. Ex. Edu., 11 (2):20-24

Raj AD yadav V and Rathod J.H.2013 impact of front line demonstration (FLD) on the yield of pulses. International J. Sci. and Res. 9(3): 1- 4.

Samui SK, Mitra S, Roy DK, Mandal AK and Saha D. 2000. Evaluation of frontline demonstration on groundnut. Journal of the Indian Society costal agricultural Research 18 (2): 180-183

Sharma AK, Kumar V, Jha SK and Sachan RC 2011 front line demonstration on Indian mustard: An impact assessment. Indian J. Ext. Edu. 11(3): 25-31.

Singh PK, 2002. Impact of participation in planning on adoption of new technology through FLD. MANAGE Extension Research Review, July -Dec. 45-48.

\section{How to cite this article:}

Singh, N.K., Sanjeev Kumar, Wazid Hasan and Anand Kumar. 2018. Impact of Frontline Demonstration of KVK on the Yield of Paddy (Sahbhagi dhan) in Nalanda District of Bihar, India. Int.J.Curr.Microbiol.App.Sci. 7(03): 3606-3610.

doi: https://doi.org/10.20546/ijcmas.2018.703.415 